\title{
Stakeholders Perspective on Communicative Competence in Industry 4.0: Walk the Talk of Informative Technologists
}

\author{
Ena Bhattacharyya ${ }^{1, *}$ \\ 121-03-26 Management and Humanities Department, Bandar Seri Iskandar, 32610 Tronoh, Perak \\ Darul Ridzuan, Malaysia
}

\begin{abstract}
In facing the challenges of era 4.0, graduates are undoubtedly faced with language and communicative competency struggle to ensure that there is ease of transition from that of the academia to the workplace. This transition would entail innovative insight in language learning to equip graduates with apt technical and non-technical competencies for purposes of employability and work readiness. Graduates will need to familiarize themselves with the professional environment and be familiar with the language of the community of practice. To be considered a legitimate member of a community, the situated learning theory postulates that continued participation and engagement over a period of time with a community, provides one the ability to be considered as member of a community. For this purpose, a mixed method research was conducted in a private university to obtain the views of graduates and employers involved in student internship programs at an Information Technology (IT) company. Respondents were required to provide their feedback on communicative competence expected of interns for employability and work readiness. The study aims to share the communicative competencies and struggles as well as pedagogical implications expected of IT graduates in Industry 4.0. to be deemed employable and work ready.
\end{abstract}

Keywords: Communicative Competence; Technical Oral Presentation; Industry 4.0; Education; Employability; Work Readiness

\section{Introduction}

The fact that supply of human capital exceeds employers' demands casts a grave concern over the employability of our graduates. This concern is further aggravated by the

* Corresponding author: ena_bhattacharyya@utp.edu.my 
mismatch between academia and industry driven skills requirement which calls for a relook at aligning human capital skills with nation-building efforts. Scores of studies affirm such mismatch and the need to align graduate attributes with employment requirements (Bridgstock, 2009; Rosenberg, Heimler, \& Morote, 2012). Cappelli (2008) makes mention that of the interdependence between employer-employees and the society at large where employers require affordable skills at specific moments of the industry, while employees seek career advancement and human capital development in the society. For this to occur, skills need to match industry requirement which must be translated to the community.

With globalization and the rapid technological borderless competition, it is without a doubt that employer's expectation of employability skills far differs from that of just mere technical skills (Fackler \& Funabashi, 2018). Studies on the term employability skills is closely related and frequently associated to similar skills such as generic capabilities, transferable skills, basic skills, essential skills, work skills, soft skills, core skills, core competencies and enabling skills or even key skills (Zaharim, Yusoff, Omar, Mohamed \& Muhamad,2009). Yet, there is limited literature to indicate the expected set of core skill requirement required for an industry. Different skills are deemed important by different employers in today's industries (Robles, 2012).

What was considered as important employability skills or work related skills in the 80 's has transformed over the centuries to more high skill demands in the advanced world (O'Neil \& O'Neil, 2014). Although it is reported that an estimated number of 100,000 graduates leave Higher Education Institutions (HEIs) every year (Singh, Thambusamy \& Ramly, 2014), yet the alarming rate of unemployed graduates leaves many to question the employability and work readiness preparedness of the said graduates. The Department of Statistics, Malaysia (2017) indicates the rate of unemployment at 3.3\% which means that graduates may not obtain immediate career placement upon graduation.

Universities and education training needs to be improve in order to lessen the gap between current employer needs and training that the graduates receive (Hernández-March, Martín del Peso \& Leguey, 2009). Employers express the need for graduates to be more confident, critical and creative in competitive global work environment. Universities need to produce graduates to meet employer needs in the industries. The exposure and teaching of soft skills requirement need to be aligned to employer needs to ensure employability.

One particular communicative event that occurs in workplace is technical oral presentations or final year project. It is this communicative event that will be investigated to comprehend stakeholders' perceptions of communicative competence necessary to gain employability and work readiness befitting of graduates in era 4.0.

\section{Literature Review}

One of the essential soft skill expected of any employer is the need to communicate successfully in the workplace environment (Kay \& Greenhill, 2011). Communication skills are acknowledged as a fundamental and imperative $21^{\text {st }}$ century skill which propagates the success or failure of sustainable nation-building negotiations and efforts (Gokool-Ramdoo \& Rumjaun, 2017; Kereluik, Mishra, Fahnoe \& Terry, 2013). In the effort to ensure continued sustenance of human capital, mastery of the English language as the language of the global world, is essential to indicate ones' readiness to be a member of the professional community, i.e. professional engineering community (Arkoudis, Hawthorne, Baik, Hawthorne, O’Loughlin, Leach \& Bexley, 2009).

One needs to be able to participate effectively as a member of the said community of practice in various types of oral and written communicative events, such as technical oral presentations, business meetings and sales presentations that take place in an organization 
(Lave \& Wenger, 1991). In the context of workplace communicative competence, graduates not only need to exhibit confidence in the mastery of the technical jargon but possess the ability to deliver, receive information and critique to and from an audience based on current scientific evidence (Celce-Murcia, 2007; Dannels, Gaffney \& Martin, 2008; Bhattacharyya, 2014).

Graduates need to exhibit confidence in technical knowledge as well as other soft skill traits which attributes to effective workplace participation. An understanding of communicative competence requirements in technical oral presentations stems from the lack of linguistic and rhetorical competency studies required among English as Second Learners (ESL) in a Malaysian setting; employer discontent over graduates' apparent lack of communication skills and limited literature on linguistic and rhetorical features necessary in scientific and engineering oral presentations (Dannels, 2009; Hafizoah Kassim \& Kassim Ali 2010; Morton, 2009). This becomes even more apparent in Industry 4.0 where the oral presentation requirements of today far differ from previous requirements. It is important that an investigation of such gap is conducted to resolve academia-industry practitioner gap over communicative competence requirements necessary for employability and work readiness of graduates in tomorrow's industry.

Workplace employability centers on the graduates' agility and ability to utilize his/her achievements skills, understandings and personal attributes that appeal to employers, to gain employment and be successful in their chosen occupations, which in turn benefits themselves, the workforce, the community and the economy (Yorke, 2008; Omar, Manaf, Mohd, Kassim \& Aziz, 2012). What this means is the employee's flexibility and ability to utilize his own skills to meet the workplace demands as required by the employers of the company (Meister, Willyerd \& Foss, 2010; Eisner, 2005; Crebert, Bates, Bell, Patrick \& Cragnolini, 2004).

Clearly, the debate over what constitutes employability skills from the perspective of the academia and industry practitioners remains a struggle yet to be resolved. Workplace readiness, on the other hand, is a relatively new concept in predicting graduate potential. To Caballero, Walker, \& Fuller-Tyszkiewicz (2011) work readiness is exemplifies the desired degree that graduates actually possess the required attitudes and attributes that enable them to be ready to face the real workplace environment. For graduates to be deemed as being work ready, one exhibits the potential, ability and rigor to overcome challenges in the workplace and are able to show their ability, success and career progression in their jobs.

\subsection{Communicative Competence Framework and Situated Learning Theory}

In relation to gaining employability and acquiring work readiness of graduates, the theory of communicative competence (Hymes, 1964) and theory of situated learning (Lave \& Wenger, 1991) aptly looks at communication practiced within a group of practitioners who share common knowledge on discourse practices in a community of practice.

Communicative competence essentially views the act of communication "as a relative and dynamic, interpersonal construct among individuals with focus on functionality and adequacy of communication, sufficiency of knowledge, judgment, and skills in linguistic competence, operational competence, social competence, and strategic competence (Light, 1989 as cited in Bhattacharyya, 2014). Grammatical competence looks at the syntactic and semantic competencies in the use of the tools of communication; while social and strategic competencies reflect functional knowledge and judgement in interaction" (Light, 1989 cited in Bhattacharyya, 2014).To Hymes, appropriacy of every grammatically correct utterance is taken into consideration as human interaction occurs in a heterogeneous speech community. 
The theory stipulates the need for a combination of competency requirement such as grammatical competence, socio-linguistic competence, strategic competence as well as discourse competence, as essential linguistic competency requirement for graduates to utilize such knowledge and skills in its appropriate context, to be considered communicatively competent. This is clearly illustrated in the framework in Figure 1 on the Theory of Communicative Competence (Canale \& Swain, 1980).

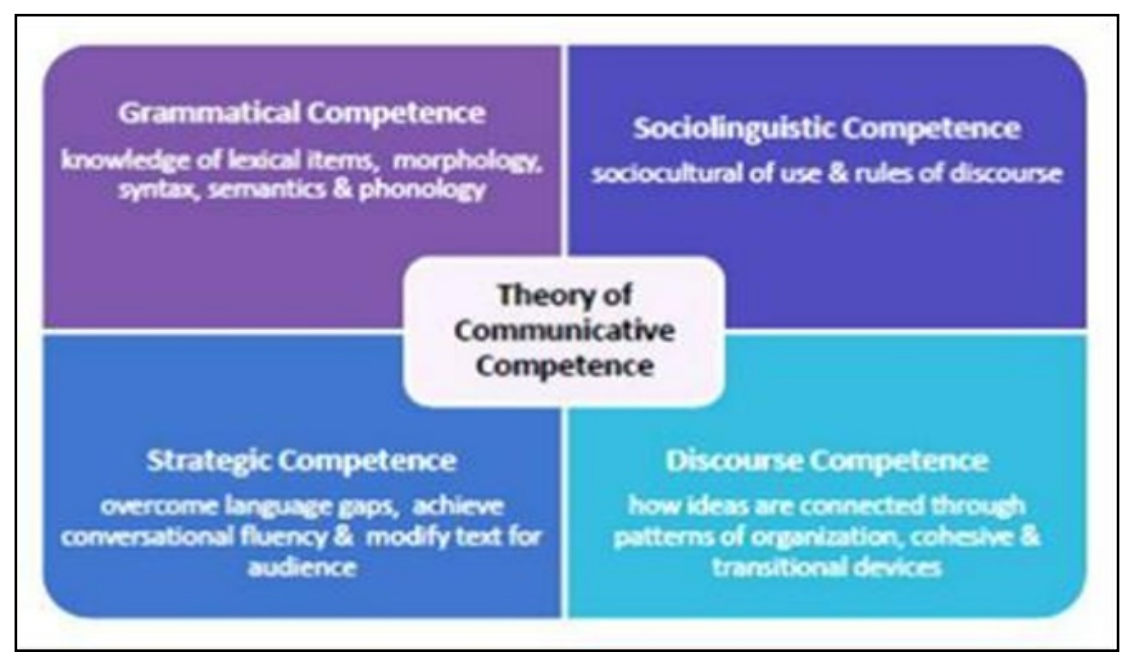

Fig. 1. The theory of Communicative Competence (Canale \& Swain, 1980)

The origins of communicative competence as stipulated in the above Figure 1 clearly illustrate the emphasis on four different linguistic competences. However, we ask ourselves, if these competencies are sufficient in today's working world and Industry 4.0 era? What other communicative competencies are necessary in today's world of work to be considered communicatively competent? Are the above competencies sufficient to ensure employability and work readiness of graduates? What other competencies are then deemed necessary in era 4.0 ?

To understand the notion of communicative competence for graduates' employability and work readiness in a community of practice, it is necessary to investigate if there exist other competencies which challenge graduates to rise above the expected norm of communicative competence as propagated by Hymes (1964).

\section{Methodology}

The methodology utilized in this study is that of mixed method research design. In this study, a quantitative and qualitative analysis is carried out to extrapolate a general consensus and followed by qualitative findings of selected respondents. For this study, a questionnaire was distributed among 207 respondents who comprised of Information Technology and Engineering Interns in various local, regional and multinational companies affiliated as industrial intern partners of the research university. Qualitative interview was further conducted at the collaborating Information Technology (IT) Industrial Internship Company which was mentoring and supervising 6 IT students who were attached as interns. 
The selected respondents in the qualitative study included employers who were also intern supervisors to the respective interns in the company.

These interns were attached for a duration of 8 months as part of the graduation requirement of the degree program. Ethical consent was obtained from the respective Heads of Department within the research university as well as the Manager of the Industrial Internship Company which was training the interns. The objective and the purpose of the study was clarified to the said personnel prior any data collection. It was also clearly stipulated that data collected was to be utilized only for academic publication purposes. The mixed method was employed as both quantitative and qualitative methods seek to complement each other and make the research more credible when they are effectively used (Creswell, 2008; Johnson \& Onwuegbuzie, 2004). Thus, it is for this reason that a mixedmethod design was employed to obtain views with selected participants on communicative competence requirement necessary in technical oral presentations or final year project to meet employability and work readiness demands for Industry 4.0.

lace the figure as close as possible after the point where it is first referenced in the text. If there is a large number of figures and tables it might be necessary to place some before their text citation.

\section{Quantitative and Qualitative Findings and Discussion}

The summary for the mean rating on communicative competence criteria exhibited in final year project is illustrated in Table 1. The average mean score indicates that the graduates rated the communicative competence criteria exhibited in final year project as being relatively high. For example, the results can be interpreted to mean that the graduates are aware of the importance to "understand the purpose of the presentation" $(M=1.73)$ or "apply suitable formal salutation or greetings to the audience" $(\mathrm{M}=1.76)$.

Table 1. Communicative Competence Criteria Exhibited in Final Year Project

\begin{tabular}{|c|c|c|c|}
\hline $\begin{array}{l}\text { COMMUNICATIVE COMPETENCE CRITERIA } \\
\text { EXHIBITED IN FINAL YEAR PROJECT }\end{array}$ & MEAN & MEDIAN & $\begin{array}{l}\text { STD. } \\
\text { DEVIATION }\end{array}$ \\
\hline Understand the purpose of the presentation & 1.73 & 2 & 0.625 \\
\hline Understand the scope of the presentation & 1.79 & 2 & 0.633 \\
\hline $\begin{array}{l}\text { Apply the correct organization pattern. i.e.: problem- } \\
\text { solution order, cause-effect }\end{array}$ & 2.04 & 2 & 0.652 \\
\hline $\begin{array}{l}\text { Apply suitable formal salutation or greetings to the } \\
\text { audience }\end{array}$ & 1.76 & 2 & 0.675 \\
\hline $\begin{array}{l}\text { Analyse the presentation material prior the real } \\
\text { presentation }\end{array}$ & 1.88 & 2 & 0.715 \\
\hline Memorize the points of the presentation & 2.15 & 2 & 0.854 \\
\hline Anticipate the possible type of questions asked & 2.15 & 2 & 0.856 \\
\hline Clarify any technical terms used in the presentation & 2.04 & 2 & 0.775 \\
\hline
\end{tabular}

Table 2 show the mean score of communicative competence response in final year project for workplace readiness which shows a high score. Some of respondents stated that during final year projects, respondents need to "defend ideas when questioned" $(\mathrm{M}=1.89)$. They also realise the importance to "listen attentively to questions posed by the audience" 
$(\mathrm{M}=1.68)$. In other words, to a competent communicator of Industry 4.0, one not only defends but also listens to the audience. All of the stated items within the said construct need to be practiced by the graduates to be considered competent in era 4.0.

Table 2. Communicative Competence Response in Final Year Project for Workplace Readiness

\begin{tabular}{|c|c|c|c|}
\hline $\begin{array}{ll}\text { COMMUNICATIVE } & \text { COMPETENCE } \\
\text { RESPONSE IN FINAL YEAR PROJECT FOR } \\
\text { WORKPLACE READINESS }\end{array}$ & MEAN & MEDIAN & $\begin{array}{l}\text { STD. } \\
\text { DEVIATION }\end{array}$ \\
\hline $\begin{array}{l}\text { Be analytical when answering the audience } \\
\text { queries }\end{array}$ & 2.13 & 2 & 0.772 \\
\hline Be flexible in answering the audience's questions & 1.96 & 2 & 0.726 \\
\hline Be courteous to the audience & 1.95 & 2 & 0.698 \\
\hline Give time to the audience to reflect on the topic & 1.98 & 2 & 0.797 \\
\hline Invite the audience to ask questions & 2.02 & 2 & 1 \\
\hline $\begin{array}{l}\text { Listen attentively to questions posed by the } \\
\text { audience }\end{array}$ & 1.68 & 2 & 0.636 \\
\hline $\begin{array}{l}\text { Incorporate audience feedback for further } \\
\text { improvement }\end{array}$ & 2.1 & 2 & 0.878 \\
\hline Respond to sudden unexpected queries & 2.12 & 2 & 0.776 \\
\hline Defend ideas when questioned & 1.89 & 2 & 0.705 \\
\hline Total Mean & 1.9791 & 2 & 0.50192 \\
\hline
\end{tabular}

In terms of language competence, Table 3 showed the mean score of Language Competence in Final Year Project for Workplace Readiness. All of elements indicated the high score and illustrated that they are highly presenting workplace readiness elements in final year project presentations. However, element of "use correct grammar at all times" acquired $\mathrm{M}=2.43$ which means nearest to "undecided" scale value. Therefore, the responsible party need to more attention on this element in order to improve workplace readiness.

Table 3. Language Competence in Final Year Project for Workplace Readiness 


\begin{tabular}{|c|c|c|c|}
\hline $\begin{array}{l}\text { LANGUAGE COMPETENCE IN FINAL } \\
\text { YEAR PROJECT FOR WORKPLACE } \\
\text { READINESS }\end{array}$ & MEAN & MEDIAN & $\begin{array}{l}\text { STD. } \\
\text { DEVIATION }\end{array}$ \\
\hline Use correct grammar at all times & 2.43 & 2 & 0.982 \\
\hline $\begin{array}{l}\text { Use appropriate language throughout the } \\
\text { delivery }\end{array}$ & 1.92 & 2 & 0.823 \\
\hline Ensure language used is easily understood & 1.78 & 2 & 0.687 \\
\hline Avoid using complex language & 1.86 & 2 & 0.736 \\
\hline Articulate the words well & 2.15 & 2 & 0.827 \\
\hline Enunciate the words clearly & 2.15 & 2 & 0.833 \\
\hline Pronounce words and names clearly & 2 & 2 & 0.815 \\
\hline Choose the appropriate words & 1.89 & 2 & 0.787 \\
\hline Total Mean & 2.0223 & 2 & 0.62769 \\
\hline
\end{tabular}

The mean score of Presenting Workplace Readiness Elements in Final Year is indicated in Table 4. The findings denote that there is a need to improve in the said items related to work readiness component. To be competently ready for an industrialized era, there needs to be emphasis critical and creative analysis, possess presentation skills necessary for global diverse type environment, team spirit as well as being computer literate. Graduates of era 4.0 need to be digitally literate to be considered employable and work ready.

Table 4. Presenting Workplace Readiness Elements in Final Year Project

\begin{tabular}{lllll}
\hline PRESENTING $\quad$ WORKPLACE & READINESS & MEA & MEDIA & STD. \\
ELEMENTS IN FINAL YEAR PROJECT & & $\mathrm{N}$ & $\mathrm{N}$ & DEVIATI \\
& & & & ON \\
\hline \hline
\end{tabular}

Present goal-relevant activities, rank them, allocate time, prepare and follow schedules

$\begin{array}{lll}2.02 & 2 & 0.788\end{array}$

Present on budgets, makes forecasts, and deliberate on adjustments to meet objectives

Present information on assessment of skills and provide feedback

$\begin{array}{lll}2.07 & 2 & 0.741 \\ 2.02 & 2 & 0.753 \\ 2.22 & 2 & 0.917 \\ 2 & 2 & 0.766 \\ & & \\ 2.05 & 2 & 0.805 \\ 1.94 & 2 & 0.644 \\ 1.82 & 2 & 0.745\end{array}$

Present to group effort

Present and teach others new skills

Present and communicate ideas to justify position

Present in dynamic groups with men and women from diverse backgrounds

Present, interpret and communicate information

Present Information by use of computers

Involved in presenting trends, prediction of impacts on system operations, diagnoses deviations in systems' performance and corrects malfunctions

Presents suggestions on modifications to existing systems

$2.07 \quad 2$


and develops new or alternative systems to improve performance

Presents information on identification, or provide solutions on problems with equipment, including

\begin{tabular}{llll} 
computers and other technologies & 2.04 & 2 & 0.793 \\
\hline & 2.076 & & \\
Total Mean & 5 & 2.0833 & 0.5653 \\
\hline \hline
\end{tabular}

The above findings as indicated in the mean score generally denote that there is a need for improvement to be considered viable graduates of industry era 4.0. In general, these findings indicated that in the current age of Industrial revolution 4.0 demand, the language and communicative competencies for workplace readiness of graduates' today's is relatively high. The respondents perceived the importance of language competency to be relatively high while the work readiness at this stage is average which needs to be improved in order to prepare graduates for better workplace readiness.

\section{Thematic Findings}

The managers provided various insights from the employers' perspective to ensure employability and work readiness. The themes derived from the findings include the importance of global competitiveness, self-accountability and ownership, time management, sense of alertness and self-reliance, accountable, self-motivated, self-driven and compassionate when assigned to tasks.

\section{Theme 1: Competitive Global Market Player}

From the perspective of an employer, trainings are provided to staff in order for staff to be a global competitive player, and be ahead of competitors. With a borderless world in the IT industry, staff must be value added with necessary technical and non-technical expertise (Rasul, Rauf, Mansor \& Puvanasvaran, 2012). Manager A mentioned,

“...We have now, you know competitors, so we need to make sure that our talent is valued and the investors are willing to come because we have competent talents..."

The employer shares the knowledge where neighboring competitors in China provide training in English language programs as part of the company's need to be communicatively competent. For the said company, the seriousness of being a global market player is indicated when a walk around the company premise indicated the presence of a "corporate academic university" and training rooms available at one of the levels of the company. Staffs are provided with daily training sessions in various skills competency programs. The employer's sentiments are mirrored in the government's nation building initiative of developing human capital (Ministry of Education Malaysia, 2012; Gibson, 2015). The willingness to equip staffs with up-to-date training and skills competencies is necessary for companies in era 4.0.

\section{Theme 2: Ecosystem for Talent Sourcing and Mobility}

The sustenance of employability and work readiness in era 4.0 is not only instrumental among the manpower but that of the organizational set up. Employers are vigilant of the staff's talents and address such competencies via mutual discussion. This means there is a 
need for both employers and graduates to have a mutual and open discussion on matching the capabilities with rightful job specifications. Manager B mentions,

“...Talents are recognized. Mutual discussions are held so that staffs are rightfully matched to the area of interest. The right ecosystem is set. There is certification for in-house training courses..."

This clearly mirrors the company's commitment to equipping its staff with the required competencies so that staffs enjoy higher remuneration in relation to the skill competency. To be employable, both employers and graduates or staffs need to match skills with specific interest areas to be able to create staff mobility within departments and outside of the company (Qomariyah, Savitri, Hadianto \& Claramita, 2016).

\section{Theme 3: Personality Trait: Self-Motivation and Self-Driven}

Employers gauge the interns' employability and work readiness for era 4.0 when staff (inclusive of interns and fulltime staff) take ownership of the task delivered. This is reflected in Manager C's response who stated the criteria of work commitment and ownership of the individual to the said task. This is clearly indicated if the individual invested in the task productively or otherwise. Manager $\mathrm{C}$ mentions the importance of employability and work readiness is judged by the individual's

“...work knowledge, ability, work habit, performance, you can see on the knowledge ability, job knowledge, whether its minimum, or over work productivity, the work quality,... whether they are really productive or not productive..."

Thus, the employability and work readiness of an individual is gauged by his or her well preparedness of the individual in taking ownership of acquiring more knowledge and performing productively on the task (Billett, 2001; Helyer \& Lee, 2014; Adnan, Daud, Alias \& Razali, 2017).

\section{Theme 4: Accountability and Time-Management Skills}

For Manager D, part of employability and work readiness ethic requirement is the importance for individuals

"to note the urgency and the importance to deliver within the timeline... if a task is delivered to the individuals on a certain time, we expect the graduates or staff to complete it urgently as clients' demand solutions for their problems. This is critical for graduates to understand..."

To Manager $\mathrm{D}$, time management is crucial as it companies revolve around datelines. The essence of time management is concurred in other employability studies (Moore \& Morton, 2017). Pedagogically, there is a need to be timely and accountable for responsibilities as individuals and in teams (Burrus, Jackson, Xi \& Steinberg,2013).

\section{Theme 5: Goal Driven and Result Oriented}


To be employable and work ready, an individual must be pro-active, talented and passionate about what he or she does. For Manager E,

"...one must be passionate as we are a business entity, you must indicate the passion...to get things done using your skill related to the software for sure..."

This finding concurs with employability studies which states the importance of passion and motivation of graduates to attain gainful employment and ensure career success (Hurst, Fowler \& Scapens, 2017). Pedagogically, one needs to have a sense of business acumen. Thus, speed and result driven analysis are important competencies expected of era 4.0. The outcome of the results from the study indicate the need to beef up on added technical and non-technical skills necessary for gainful employment and work readiness in era 4.0. As technological innovation occurs at a rapid pace, there is a need to improve and equip graduates with the apt skills. For this to materialize, educators need to be aware and equip graduates with skills of the digital era.

\section{Conclusion}

To be considered viable and competent as indicated by the findings, it is clear that graduates of today cannot solely be assured by linguistic competence. More importantly for one to be considered employable and work ready, various other attributes and skills have been perceived as determinants in era 4.0. It is skills such as adaptability, critical and innovative entrepreneurial mind-set, accountability, goal driven and passionate are some of the many skills deemed pertinent to be employable and work ready. Both educators and industry practitioners need to be engaged in more mutual learning platforms that share mutual input on employability skills and work readiness. The synergy between academiaindustry partnership platforms need to be enhanced to meet the demands of era 4.0 and beyond. Through such methods, pedagogical innovation in classroom input on employability and work readiness will gradually be enhanced and thus meet industry demands to allow graduates to eventually walk the talk of industry practitioners.

The researcher wishes to acknowledge the funding provided by the University Internal Research Funding and sincere thanks to all respondents involved in the study.

\section{References}

Adnan, Y. M., Daud, M. N., Alias, A., \& Razali, M. N. (2017). Importance of soft skills for graduates in the real estate programmes in Malaysia. Journal of Surveying, Construction and Property, 3(2).

Arkoudis, S., Hawthorne, L., Baik, C., Hawthorne, G., O’Loughlin, K., Leach, D., \& Bexley, E. (2009). The impact of English language proficiency and workplace readiness on employment outcomes and performance of tertiary international students. Melbourne: Centre for the Study of Higher Education, University of Melbourne.

Baird, A. M. (2016). 21 st Century Workforce: Employers' Ratings of Importance and Satisfaction of Skills and Competencies College Graduates Need to Get Hired in the Northeast (Doctoral dissertation, Johnson \& Wales University).

Bhattacharyya, E. (2014). A case study of stakeholder perceptions on communicative competence in engineering technical oral presentation (Doctoral dissertation, University Malaya). 
Bridgstock, R. (2009). The graduate attributes we've overlooked: Enhancing graduate employability through career management skills. Higher Education Research \& Development, 28(1), 31-44.

Burrus, J., Jackson, T., Xi, N., \& Steinberg, J. (2013). Identifying the most important 21st century workforce competencies: An analysis of the Occupational Information Network ( $O^{*} N E T$ (Research Report No. RR-13-21). Princeton, NJ: Educational Testing Service.

Caballero, C. L., Walker, A., \& Fuller-Tyszkiewicz, M. (2011). The work readiness scale (WRS): Developing a measure to assess work readiness in college graduates. Journal of teaching and learning for graduate employability, 2(2), 41-54.

Canale, Michael, \& Swain, Merrill. (1980). Approaches to communicative competence (pp. 63). Singapore: SEAMEO Regional Language Centre.

Cappelli, P. (2008), "Talent management for the twenty-first century", Harvard Business Review, Vol. 86 No. 3, pp. 74-81.

Celce-Murcia, M. (2007). Rethinking the role of communicative competence in language teaching. In Eva Alcón Soler \& Maria Pilar Safont Jordà (Eds.), Intercultural Language Use and Language Learning (pp. 41-57). Dordrecht, The Netherlands: Springer.

Crebert, G., Bates, M., Bell, B., Patrick, C. J., \& Cragnolini, V. (2004). Developing generic skills at university, during work placement and in employment: graduates' perceptions. Higher Education Research \& Development, 23(2), 147-165.

Creswell, John W. (2008). Educational Research: Planning,conducting and evaluating quantitative and qualitative research (3rd ed.). Upper Saddle River, New Jersey: Pearson Prentice Hall.

Dannels, Deanna P. (2009). Features of success in engineering design presentations: A call for relational genre knowledge. Journal of Business and Technical Communication, 23, 399-427.

Dannels, Deanna P., Gaffney, Amy , \& Martin, Kelly. (2008). Beyond content, deeper than delivery: What critique feedback reveals about communication expectations in Design Education. International Journal for the Scholarship of Teaching and Learning, 2(2), 1-16.

Department of Statistics, Malaysia (2017), Key Statistics of Labour Force in Malaysia, November 2017, Ministry of Human Resource.

Eisner, S. P. (2005). Managing generation Y. SAM Advanced Management Journal, 70(4), 4.

Fackler, M., \& Funabashi, Y. (Eds.). (2018). Reinventing Japan: New Directions in Global Leadership. ABC-CLIO.

Gibson, J. A. (2015). Reimagining the Rhetorical Canons for Professional Communication Pedagogy.

Gokool-Ramdoo, S., \& Rumjaun, A. B. (2017). Education for sustainable development: Connecting the dots for sustainability. Journal of Learning for DevelopmentJL4D, 4(1).

Hafizoah Kassim, \& Fatimah Ali. (2010). English communicative events and skills needed at the workplace: Feedback from the industry English for Specific Purposes, 29(3), 168-182.

Hernández-March, J., Martín del Peso, M., \& Leguey, S. (2009). Graduates’ skills and higher education: The employers' perspective. Tertiary education and management, 15(1), 1-16.

Helyer, R., \& Lee, D. (2014). The role of work experience in the future employability of higher education graduates. Higher Education Quarterly, 68(3), 348-372. 
Hurst, C., Fowler, J., \& Scapens, G. (2017). Sustainable employability in higher education: Career development outside of the curriculum. In Success in Higher Education (pp. 217-228). Springer, Singapore.

Hymes, Dell. (1964). Introduction: Toward ethnographies of communication. American Anthropologist, 66, Number 6 (Part 2), 1-34.

Johnson, R.B., \& Onwuegbuzie, A.J. (2004). Mixed methods research: A research paradigm whose time has come. Educational Researcher, 33(7), 14 - 26

Kay, K., \& Greenhill, V. (2011). Twenty-first century students need 21 st century skills. In Bringing schools into the 21 st century (pp. 41-65). Springer Netherlands.

Kereluik, K., Mishra, P., Fahnoe, C., \& Terry, L. (2013). What knowledge is of most worth: Teacher knowledge for 21 st century learning. Journal of Digital Learning in Teacher Education, 29(4), 127-140.

Lave, J., \& Wenger, E. (1991). Situated learning: Legitimate peripheral participation. Cambridge, UK: Cambridge University Press.

Meister, J. C., Willyerd, K., \& Foss, E. (2010). The 2020 workplace: How innovative companies attract, develop, and keep tomorrow's employees today (p. 5). New York, NY: Harper Business.

Ministry of Education Malaysia. (2012). Malaysia education blueprint 2013-2025.

Moore, T., \& Morton, J. (2017). The myth of job readiness? Written communication, employability, and the 'skills gap' in higher education. Studies in Higher Education, 42(3), 591-609.

Morton, Janne. (2009). Genre and disciplinary competence: A case study of contextualisation in an academic speech genre. English for Specific Purposes, 28, 217-229.

Omar, N. H., Manaf, A. A., Mohd, R. H., Kassim, A. C., \& Aziz, K. A. (2012). Graduates' employability skills based on current job demand through electronic advertisement. Asian Social Science, 8(9), 103.

O'Neil Jr, H. F., \& O'Neil, H. F. (2014). Workforce readiness: Competencies and assessment. Psychology Press.

Qomariyah, N., Savitri, T., Hadianto, T., \& Claramita, M. (2016). Formulating Employability Skills for Graduates of Public Health Study Program. International Journal of Evaluation and Research in Education, 5(1), 22-31.

Rasul, M. S., Rauf, R. A. A., Mansor, A. N. \& Puvanasvaran, A. P. (2012). Employability skills assessment tool development. International Education Studies, 5(5), 43.

Robles, M. M. (2012). Executive perceptions of the top 10 soft skills needed in today's workplace. Business Communication Quarterly, 75(4), 453-465.

Rosenberg, S., Heimler, R., \& Morote, E. S. (2012). Basic employability skills: a triangular design approach. Education+ Training, 54(1), 7-20.

Singh, P., Thambusamy, R. X., \& Ramly, M. A. (2014). Fit or unfit? Perspectives of employers and university instructors of graduates' generic skills. Procedia-Social and Behavioral Sciences, 123, 315-324.

Yorke, M. (2008). Employability in higher education: What it is and what it is not. Higher Education Academy: ESECT.

Zaharim, A., Yusoff, Y., Omar, M. Z., Mohamed, A., \& Muhamad, N. (2009, July). Engineering employability skills required by employers in Asia. In Proceedings of the 6th WSEAS international conference on Engineering education (pp. 195-201). 